\title{
Games for and by teachers and learners
}

Citation for published version (APA):

van Rosmalen, P., Wilson, A., \& Hummel, H. (2014). Games for and by teachers and learners. In T. M. Connolly, T. Hainey, E. Boyle, G. Baxter, \& P. Moreno-Ger (Eds.), Psychology, pedagogy, and assessment in serious games (1 ed., pp. 243-269). IGI Global. https://doi.org/10.4018/978-1-4666-4773-2.ch012

DOI:

10.4018/978-1-4666-4773-2.ch012

Document status and date:

Published: 01/01/2014

Document Version:

Peer reviewed version

Document license:

CC BY-NC-SA

Please check the document version of this publication:

- A submitted manuscript is the version of the article upon submission and before peer-review. There can be important differences between the submitted version and the official published version of record. People interested in the research are advised to contact the author for the final version of the publication, or visit the DOI to the publisher's website.

- The final author version and the galley proof are versions of the publication after peer review.

- The final published version features the final layout of the paper including the volume, issue and page numbers.

Link to publication

\section{General rights}

Copyright and moral rights for the publications made accessible in the public portal are retained by the authors and/or other copyright owners and it is a condition of accessing publications that users recognise and abide by the legal requirements associated with these rights.

- Users may download and print one copy of any publication from the public portal for the purpose of private study or research.

- You may not further distribute the material or use it for any profit-making activity or commercial gain

- You may freely distribute the URL identifying the publication in the public portal.

If the publication is distributed under the terms of Article 25fa of the Dutch Copyright Act, indicated by the "Taverne" license above, please follow below link for the End User Agreement:

https://www.ou.nl/taverne-agreement

Take down policy

If you believe that this document breaches copyright please contact us at:

pure-support@ou.nl

providing details and we will investigate your claim.

Downloaded from https://research.ou.nl/ on date: 26 Apr. 2023 


\title{
Games For and By Teachers and Learners
}

\author{
Peter van Rosmalen ${ }^{1}$, Amanda Wilson ${ }^{2}$, Hans Hummel ${ }^{1}$ \\ ${ }^{1}$ Open University of the Netherlands, Centre for Learning Sciences and Technologies (CELSTEC), The \\ Netherlands \& ${ }^{2}$ University of the West of Scotland, UK
}

Keywords: serious gaming; design games; simple games; gamification, teacher training

\begin{abstract}
With the advent of social media it is widely accepted that teachers and learners are not only consumers but also may have an active role in contributing and co-creating lesson materials and content. Paradoxically one strand of technology enhanced learning, i.e. game-based learning, aligns only slightly to this development. Games while there to experience, explore and collaborate are almost exclusively designed by professionals. Despite, or maybe because, games are the exclusive domain of professional developers, the general impression is that games require complex technologies and that games are difficult to organise and to embed in a curriculum. This chapter will make a case that games are not necessarily the exclusive domain of game professionals. Rather than enforcing teachers to get acquainted with and use complex, technically demanding games, we will discuss approaches that teachers themselves can use to build games, make use of existing games and even one step beyond use tools or games that can be used by learners to create their own designs, e.g. games or virtual worlds.
\end{abstract}

\section{INTRODUCTION}

With the advent of social media it is widely accepted that teachers and learners are not only consumers but also may have an active role in sharing and co-creating content, debate and share opinions (Silius et al., 2010). Social media such as social networks, online videos and wikis are not merely used to connect or entertain but also support informal learning (Sloep et al., 2011) by enabling learners to ask questions, to debate and to share opinions and materials with other learners. Online videos with a variety of learning content are widely shared and used by individuals and in the classroom. Wikis, essentially no more than a website with facilities for creating, editing, linking and navigating web pages, fit very well into the Web 2.0 paradigm of user involvement and user created content. They are, because of their ease of use and because they allow users to be actively involved, widely used in education for a variety of applications (see e.g. Ayers \& Ortega, 2010; Riehle \& Bruckman, 2009) such as notes sharing, collaborative writing, exchange of ideas, e-portfolios, shared learning tasks, getting used to ICT, and writing multi-media essays and project reports. Paradoxically, one strand of technology enhanced learning, i.e. game-based learning, aligns slightly with this development. Games, while there to experience, explore and collaborate, are almost exclusively designed by professionals, despite the fact that one of the first game-like learning environments, i.e. Turtle Logo (Fischer \& Kling, 1974), was created to have learners explore their creativity by building their own miniprogrammes. In most cases, games offer closed worlds or scenarios and teacher and learners can only act within the options given. Despite, or maybe because, games are the exclusive domain of professional developers, the general impression is that games require complex technologies and that games are difficult to organise and to embed in education curriculum. The latter is of importance since the use of ICT and games, in particular, only tends to be successful if it closely fits with the existing teaching practice (Vier in Balans Monitor, 2012, pp 45).

Although the domestic market of video entertainment games has been a fast-moving field over a number of years with annual growth rates well above 10\% (PWC, 2010; National Gaming Survey, 2009), the use of games for educational purposes has remained quite limited (Ten Brummelhuis \& Van Amerongen, 2010; Klopfer, Osterweil, \& Salen, 2009). Barriers identified in the literature include 
teachers' lack of expertise, aspects of the school system, financial barriers and technical barriers (NFER, 2009). Only few data are available describing teachers' opinions on using games in their classrooms. In a survey (NFER, 2009) among 1632 UK primary and secondary school teachers, the majority of teachers $(85 \%)$ were predominantly positive about what could be learnt or developed as a result of playing computer games. The overall impression, however, is that many teachers are interested in game-based learning but experience severe barriers for using these in their classrooms (Van Rosmalen \& Westera, 2012; Razak, Connolly \& Hainey, 2011):

- Expertise barriers. Williamson (2009) reports an urgent need for the training of teachers who wish to gain a better understanding of how to use games in their classrooms as well as understanding the implications of games as cultural forms of young people's lives.

- Systemic barriers. Klopfer, Osterweil and Salen (2009) blame the school system for their reluctance of giving up text books or purchasing educational technologies that are not clearly linked to existing curriculum standards and the formal assessment standards. They notice that teachers find it difficult to integrate the play of a game within the fixed time structure of their schools Furthermore, within the school system teachers lack the time, incentives and support for this work. Role models that could demonstrate new modes of teaching are avoided. Finally, hardly any tools are available for teachers for adjusting existing game contents, for arranging subscriptions for their students, for setting up different game runs, for allocating different roles to different students, for monitoring the performances of their students, or guidelines how to provide guidance and support.

- Financial barriers. The high price and lack of licensing agreements for games prohibit many schools from using these resources (Williamson, 2009). For teachers it is difficult to find game contents that match their needs. The education market displays limited sources of funding. Game companies and venture capitalists are unresponsive to investing in risky products, particularly in educational technology markets that have proven to be rarely successful (FAS, 2006).

- Technical barriers. Games as well as game development are inherently complex (Westera et al., 2008). For schools it is difficult to run their own games server or to arrange their own game development. Although increasingly online web-based games are coming available that conform to cross platform browser standards, there is a lack of dedicated equipment, in particular, up-todate video/graphics cards, making it difficult for teachers to use games in their classrooms (De Freitas, 2006).

The objective of this chapter is to make a case and exemplify that games are not necessarily the exclusive domain of game professionals. Rather than forcing teachers to get acquainted with and use complex, technical demanding games, we will discuss approaches that teachers themselves can use to build games, make use of existing games and even one step beyond use tools or games that can be used by learners to create their own designs, e.g. games and virtual worlds.

In this chapter we will first provide a general overview of games for and by teachers and learners. We will discuss a variety of examples and their requirements and characteristics. Next, we will present three case studies. In case study one, we will discuss the use of wikis to build serious games. We will examine two examples; one in higher education and one in primary education, both aimed at the learning of a complex cognitive skill; i.e. argumentation and verb conjugation, respectively, and finally, it will be illustrated how teachers can make their own wiki-game. The second case study will discuss a game environment currently under development for scripting collaboration in games. It describes and reviews a first implementation of a mastership game for teachers-in-training and discusses how teachers can flexibly adapt and extend the game play by adding their own structure and 
content to fit their needs. Finally, case three will discuss Scratch, an environment designed for learners to design and develop their own programs or games. The case will discuss an example in which Scratch (Wilson, Hainey \& Connolly, 2012) was used as part of a curriculum in primary education to teach children programming concepts and programming. Lastly, the case will also review some other examples in the literature of how Scratch has been used. The chapter will conclude with a discussion and conclusions.

\section{GAMES FOR AND BY TEACHERS AND LEARNERS: AN OVERVIEW}

Although games nowadays are commonly associated with complex, immersive worlds featuring high quality graphics and smooth and fast interactions, this is not the only way to consider games. Games such as board games, with a relatively simple set of rules, have been popular for centuries. The main underlying game principles such as competition, individual challenge, collaboration, and recognition by others (Pernin, Michau, Mandran \& Mariais, 2012) have shown to be motivating and successful. For teachers, there are many, simple tools for making such a serious game, e.g. by considering a wiki (Van Rosmalen, \& Westera, 2012). Other more complex alternatives constitute of game engines with templates which teachers can modify within given constraints or to which they can add their own content (Hummel, Geerts, Slootmaker, Kuipers, \& Westera, in press) or game engines with relatively simple editors which do not require specialised expertise (Torrente, Del Blanco, Marchiori, MorenoGer, \& Fernández-Manjón, 2010; Overmars, 2004). Alternatively, following in the footsteps of Turtle Logo, teachers can position their learners in a designer role by making use of environments that enable the learners themselves to design or program examples (Maloney et al., 2008; Chou et al., 2011; Wilson, Hainey, \& Connolly, 2012). In this section we will discuss a number of such examples going from simple general, yet promising tools through more advanced game environments that can be used by teachers to create games, to examples which are suited for learners.

\subsection{Simple Tools for Games and Simple Games}

As in regular games and in computer-based games there is a long tradition for simple games based on e.g. email (see for example Play by Email games http://www.pbm.com/ lindahl/pbm_list/) or, more recent, twitter (http://playgen.com/play/twitter-game/ or http://tweepi.com/blog/2011/07/4-mostaddictive-twitter-games/). Though no literature could be found on their use in education, examples such as Artwiculate (@artwiculate), which intends to assist in learning a new word each day, or Twitbrain (@twitbrain) a game posting a math problem to be solved as quickly as possible, clearly have an educational potential. Similar there is a variety of online puzzles such as word games that, though designed for entertainment, may be used in education. Well known examples are mobile games such as Wordfeud (a scrabble-like game), Ruzzle (a word game to create as many words as possible with the letters of a $4 * 4$ board in a given time) or Draw Something (a social drawing game to guess words). It should be relatively straightforward to use these games or comparable ones as part of a lesson plan for motivational aspects or for simple, well defined learning objectives.

There are many more options for making a simple, serious game by considering a wiki. A wiki, essentially, is no more than a website with facilities for creating, editing, linking and navigating web pages. Wikis have been around for over a decade and fit very well into the Web 2.0 paradigm of user involvement and user created content. Because of their ease of use and because they allow users to be actively involved they are widely used in education for a variety of applications (see e.g. Ayers \& Ortega, 2010; Riehle \& Bruckman, 2009) such as notes sharing, collaborative writing, exchange of ideas, e-portfolios, shared learning tasks, getting used to ICT, and writing multi-media essays and project reports. Not surprisingly, wikis can also be used to build serious games. These games may be limited to relatively simple game mechanics but because of their sophisticated and easy to use tools, 
Games For and By Teachers and Learners to appear in Connolly, T.M., Boyle, E., Hainey, T., Baxter, G. \& Moreno-Ger, P. (Eds) Psychology, Pedagogy and Assessment in Serious Games.

they still can be used to practice complex skills (Van Rosmalen \& Westera, 2012; Bronk \& Van Rosmalen, submitted). In section 3.1 we will review two examples of these so called wiki-games.

\subsection{Game Engines for Teachers}

Above we discussed examples of simple tools and games (see also table 1) that teachers can use to either create a game or adopt one to be used within their lesson design. The strength of this approach is that it can be used by any teacher. However, the game elements that can be used are limited since the tools discussed do not easily allow the teacher to add any complex rules or immersive experiences. An alternative therefore is to use dedicated game design tools. Tools suitable for teachers vary in their flexibility and complexity (table 1). They start with tools that are pre-designed around a specific setting or offer a limited set of templates. One example is a 'collaboration scripting' authoring environment (Hummel et al., in press). It offers a set of adjustable parameters that are dedicated to guide and execute a collaboration script with varying structures and contents. It will be discussed in detail in section 3.2. A second example is ARLearn (Ternier, Klemke, Kalz, Van Ulzen \& Specht, 2012). ARLearn is a location-based game engine that manages games and runs media items (e.g. multiple-choice questions, video objects and narrative items) and dependencies between these media items. The most interesting aspect of ARLearn is that it offers an immersive experience in an easy and affordable way. With an Android client, game play in the real world is possible; a StreetLearn client built on top of Google Street view offers game functionality in a virtual environment. ARLearn media items can be positioned on a map and can be made available as defined in the game logic. A video can be bound to a coordinate, but can also at a certain moment appear as a message in the player's inbox. The clients can be used independently or together; e.g. one player can take the role of an operator in StreetLearn, while other players take a different role with the smart phone client. Though the editing part of the environment is still under development, the first experiments indicate that it is relatively straight forward for teachers to design game scenarios.

eAdventure (http://e-adventure.e-ucm.es/), in contrast to ARLearn, designed from scratch to be used by teachers, is an authoring tool for the creation of point-and-click adventure video games for educational purposes. It uses a graphical interface for authoring and does not require programming skills. The games are standard (SCORM) compliant and, therefore, can be easily integrated into existing e-learning environments. An eAdventure game consists of one or more chapters with each chapter being a set of scenes and cut-scenes. In scenes the actions are designed, i.e. the players' interactions with objects and characters in the game. Cut-scenes are used to display slides or images (Slidescenes) or video (Videoscenes). eAdventure (Torrente et al., 2010) has been successfully applied in a variety of games (see http://www.ub.edu/euelearning/ProActive_GBL_Repository).

An essential element in designing a game in ARLearn, eAdventure and many other game toolkits is a narrative, script or didactic scenario. It is a fundamental element of the game design. It fosters the effective acquisition of more complex skills, since it gives the learners direction and guidance in exploring a more complex case problem to reach a professional solution. Without defining the problem to tackle, the role the student has to assume when solving this problem, the methodical steps to take in order to reach a professional solution, and the tools and sources to use en route, such game play would become aimless and coincidental.

Such narratives (or didactic scenarios) may take conflicts as starting points for learning, for discovering multiple aspects and perspectives of a problem. Conflicts can entail physical or mental obstacles, different perspectives, stakeholders and / or ethical dilemmas. For instance, when setting up a new business one partner can be made responsible to ensure that investments are sustainable and will not damage the natural environment, while another partner's main job is to guarantee that initial investments actually pay off. Besides entrepreneurial finance, such conflicts are often found in health 
care, governance and policy making, and other multi-disciplinary domains where experts from different disciplines have to work together to reach solutions and compromises, such as in water management. In one of our case studies, for instance, user conflicts when solving a water management problem have to be exchanged, reflected upon, and integrated by both taking an ecological and governmental perspective on the case.

Below a more concrete idea is described on how roles, perspectives, and collaboration to reach agreement could be elaborated in a didactic scenario. It describes the setup of the 'aquaculture' case (Hummel et al., 2011) developed with EMERGO. EMERGO (Nadolski et al., 2008) is a game engine to actively acquire complex cognitive skills. It is relatively easy to use. However, unlike eAdventure, it is not designed for teachers specifically. Its authoring interface is geared to professional users.

\section{Didactic Scenario}

Background. Aquaculture is a relatively new sector (in the Netherlands). Governmental and licensing institutions still struggle to find their way in dealing with entrepreneurs who want to start a new business in this sector, especially because aquaculture can become manifest in many ways and because current legislation can be contradictory and leaves room for subjective interpretation. Economic interests often do not coincide with the interest of (especially saline/marine) agriculture or recreation. Water management professionals have to deal with conflicts and dilemmas, and need to negotiate in order to reach agreement amongst various stakeholders involved in the development area. To assess the feasibility of new activity, professionals need extensive knowledge of water streams and water quality. The field of water management therefore is in need of professionals with a rather broad background who can approach these decisions from both an ecological (nature) and governance (policy) perspective.

Scenario. At the outset of the narrative of the "Aquaculture" game, the student is assigned the role of an externally hired advisor (working at a renowned foreign consultancy agency), and is asked to get to the Netherlands to investigate and draw up a feasibility report on what would be the most suitable location to start a new shellfish production site in a saline Volkerak Zoom Lake (VZL). After becoming sufficiently oriented on the task as a project leader, the student will be asked to deliver a first version of an elaborated and argued table of contents for the report, in which both perspectives (ecological and governance) have to be represented. By this point of time students will have discovered how complex this task is, which stakeholders have to be considered, and which dilemmas play a role.

The next step in the didactic scenario is the (virtual) collaboration script. The head of the consultancy agency now asks the student (still in the role of project leader) to make a choice: to continue elaborating the report from either an ecological or governance perspective. The head takes care to fly in a (virtual) colleague who will choose the other perspective and will collaborate with the student. When the student opts for the ecological perspective the focus will be on nutrient streams and flourishing of alga, ecological possibilities and the maximum exploitation of the area; user conflicts will be left out of scope. When the student opts for the governance perspective the focus will move to various stakeholders and their demands, policy and procedures for shellfish cultivation and the VZL area whereas suitable species, nursing methods and production numbers will be left out of scope. When the table of contents has been sufficiently worked out from the chosen perspective, an email with this preliminary (necessarily partial) elaboration of the report is sent to the (virtual) colleague for inspiration and reflection, and at the same time to the (real life) tutor of the course for assessment. In reality it will be the tutor who takes care that the student now receives the (also necessarily partial) elaboration from the colleague who took the other stance. Receipt is guaranteed within the next 24 hours (for an already running course, the tutor might pick a worked example from a growing stack of student works). Finally, the student has to reflect on and integrate both partial elaborations that will be confronting or contradictory, in the final advisory report to be sent and assessed as the individual learning outcome of this game.

\subsection{Game Engines for Learners}

Continuing on from games by teachers, it is only a very small step to start thinking about games by learners (table 1). Most of the current generation of students are very familiar with games. Therefore it 
should fit very well with their interests to have students develop their own games and have them experience what it is to design and develop a game. To have students make their own computer applications is already a relatively old application. One of the first examples was Turtle LOGO, a programming environment for students. Gerard Fischer (Fischer \& Kling, 1974) used Turtle LOGO to study the development of creativity in students in combination with the development of simple computer programs. A recent, much more advanced example is Lego Mindstorms (Chou et al., 2011). Lego Mindstorms is a Lego kit including motor, sensors and a programmer environment that allows students to build and program robots. Lego Mindstorms is used to give students a compelling introduction to contemporary technology. Students can design, build, program and test their own robot. It appeals to their creative and technical skills and gives an idea of how an "intelligent" robots works. For many years, there are also quite a number of other game environments, which unlike Lego Mindstorms, only require a computer, which are suitable or designed to be used by students. Overmars (2004) discusses various, still existing, tools including simple ones such as StageCast (www.stagecast.com) and Clickteam (www.clickteam.com) and, in detail, Gamemaker (http://www.yoyogames.com/) initially developed by himself. StageCast is a tool specifically for children, in which the user defines rules that link existing graphical situations to new situations, also Clickteam offers relatively simple to use tools to create games. Gamemaker is similar to eAdventure, a rapid-application development tool. It offers drag-and-drop techniques, so users can create games without real programming but it also includes a programming language. It is successfully in use for almost a decade and it is, in particular, popular to teach computer science and related topics.

A recent example is Scratch (Maloney et al., 2008). Scratch is a package that allows users develop interactive stories, games, animations and simulations. MIT developed a curriculum in 2012 of 20 lessons in which the students get to work with Scratch. The purpose behind the curriculum is to get students acquainted with creative computing (Brennan, Chung \& Hawson, 2011). Many young people use the computer primarily as a consumer. When doing creative computing, students draw on their creativity and their computational skills to create something; i.e. they should select or create sound, pictures and devise a storyline and rely on their skills to combine this with the help of a formal computer program (e.g. use loops and conditions, and test and incrementally improve their program). The third example uses Minecraft (www.minecraft.net). Minecraft is an adventure game in which players make their tools and build or modify their environment using basic building blocks. Minecraft is not only for technical and mathematical subjects, but can also, for example, be used for communication and language learning (Schifter, 2012). Using Minecraft in education is still in development, but the advantage is that it makes use of an existing popular game. It should be clear from the above description that it will require effort to use and integrate the games discussed in the curriculum. The growing communities around these games do show it is possible and that with the growing amount of examples it will become stepwise more easy to adapt or make one's own examples. A detailed example of one of the environments, Scratch, will be discussed in section 4 .

Table 1. Overview of games for and by teachers and learners.

\begin{tabular}{|l|l|l|l|l|l|}
\hline & $\begin{array}{l}\text { Teache } \\
\text { r/ } \\
\text { Learner }\end{array}$ & $\begin{array}{l}\text { Comple } \\
\text { xity } \\
(1-3)\end{array}$ & Description & Source & Supporting materials \\
\hline $\begin{array}{l}\text { Twitter/Em } \\
\text { ail }\end{array}$ & $\mathrm{T}$ & 1 & Simple game & $\begin{array}{l}\text { http://tweepi.com/blog/2011/07/4- } \\
\text { most-addictive-twitter-games/ } \\
\text { http://www.pbm.com/ lindahl/pbm } \\
\text { list/ }\end{array}$ & n.a. \\
\hline Wordfeud & $\mathrm{T}$ & 1 & Word game & http://wordfeud.com/ & n.a. \\
\hline
\end{tabular}


Games For and By Teachers and Learners to appear in Connolly, T.M., Boyle, E., Hainey, T., Baxter, G. \& Moreno-Ger, P. (Eds) Psychology, Pedagogy and Assessment in Serious Games.

\begin{tabular}{|c|c|c|c|c|c|}
\hline $\begin{array}{l}\text { Ruzzle } \\
\text { Draw } \\
\text { something }\end{array}$ & & & & $\begin{array}{l}\text { http://www.ruzzle-game.com/ } \\
\text { http://drawsomethinggameonline.co } \\
\mathrm{m} /\end{array}$ & \\
\hline Wiki-games & $\mathrm{T}$ & $1 / 2$ & Simple game & $\begin{array}{l}\text { http://wiki-games-argument- } \\
\text { sjabloon.wikispaces.com/ }\end{array}$ & See source \\
\hline $\begin{array}{l}\text { Collaboratio } \\
\text { n scripts }\end{array}$ & $\mathrm{T}$ & 2 & $\begin{array}{l}\text { Collaboration } \\
\text { scripts }\end{array}$ & Under development & n.a. \\
\hline ARLearn & $\mathrm{T}$ & 3 & $\begin{array}{l}\text { Location } \\
\text { based game }\end{array}$ & $\begin{array}{l}\text { Under development } \\
\text { http://code.google.com/p/arlearn/ }\end{array}$ & See source \\
\hline eAdventure & $\mathrm{T}$ & $2 / 3$ & $\begin{array}{l}\text { 3D/Video } \\
\text { game }\end{array}$ & http://e-adventure.e-ucm.es & $\begin{array}{l}\text { http://e-adventure.e- } \\
\text { ucm.es/tutorial/ }\end{array}$ \\
\hline EMERGO & $\mathrm{T}$ & $3+$ & $\begin{array}{l}\text { Scenario } \\
\text { game }\end{array}$ & http://www.emergo.cc & See source \\
\hline Gamemaker & $\mathrm{L} / \mathrm{T}$ & 3 & $\begin{array}{l}\text { Game } \\
\text { construction }\end{array}$ & http://www.yoyogames.com/ & $\begin{array}{l}\text { http://gmc.yoyogames.c } \\
\text { om/ }\end{array}$ \\
\hline Scratch & $\mathrm{L}$ & $1 / 2$ & $\begin{array}{l}\text { Game } \\
\text { construction }\end{array}$ & http://scratch.mit.edu & $\begin{array}{l}\text { http://scratched.media.m } \\
\text { it.edu/resources }\end{array}$ \\
\hline $\begin{array}{l}\text { Lego } \\
\text { Mindstorms }\end{array}$ & $\mathrm{L}$ & 3 & $\begin{array}{l}\text { Construction } \\
\text { game }\end{array}$ & http://mindstorms.lego.com & $\begin{array}{l}\text { http://www.legoengineer } \\
\text { ing.com/teaching- } \\
\text { resources.html } \\
\text { http://www.roberta- } \\
\text { home.de/en }\end{array}$ \\
\hline Minecraft & $\mathrm{L}$ & 2 & $\begin{array}{l}\text { Construction } \\
\text { game }\end{array}$ & http://www.minecraft.net & http://minecraftedu.com/ \\
\hline
\end{tabular}

\section{GAMES FOR AND BY TEACHERS}

This section reviews two case studies of tools that can be used by teachers to design or adapt their own games. The first case study in this section discusses the use of an everyday tool, a wiki, to build serious games. As introduced in section 2, wikis are relatively powerful, yet easy and commonly used tools and fit very well into the Web 2.0 paradigm of user involvement and user created content. In our first case study we will see how wikis are used to create simple but motivating and useful games.

The second case study in this section describes an online collaboration game that facilitates teachersin-training to deal with classroom management dilemmas. The script to support these students in collaborating on such practical tasks, independent of teacher intervention, as well as the content delivered by the players can be worked out in various online versions of a 'mastership' game. In section 3.2 we will further explain how the structure of the collaboration script can be adapted for every run, and how players will add their individual content to build unique runs. After assigning and discussing practical dilemmas during a small group play session, solutions are worked out individually in the form of small advisory reports, uploaded to the environment and assessed by both teachers and peers (co-players in the group).

\subsection{Wiki-games}

The design and development of wiki-games started with the objective to challenge the serious games adoption barriers discussed in the introduction. The central research question of this challenge was to research to what extent it is possible to use commonly available and easy to use tools such as wikis to introduce serious games in education. More specific research questions were:

- Is it feasible at all to create appropriate and representative game scenarios in a wiki? 
- Is there any learning and/or motivation effect?

- What are the teachers' and learners' experiences?

The research was done with the help of students of a Master Programme of Learning Sciences at the Open University of the Netherlands in two consecutive studies. For study 1 an argumentation game was designed. Argumentation is an important skill since it promotes the learner's ability to get into the details of a chosen topic; i.e. to find and connect information on a topic, to discuss and defend a topic from a given position, and to disprove counter-arguments raised by their opponent. Argumentation also fits very well within a wiki since wikis allow for creating, editing and linking to text. For study 2 some of the students designed their own wiki game for their learners. The topics chosen for their wikigames ranged from how to spell verbs (primary education), radiology, freedom of speech to research methods (higher education). There was a variety of implementations ranging from minor modifications to new designs inspired by Argument. One of the resulting games, Werk!Woord!, a game on verb spelling, was also evaluated in the class room. The design and the results of the studies with Argument and Werk!Woord! are described below. Both studies followed a mainly qualitative research design.

Argument. The Argument game (Van Rosmalen \& Westera, 2012) makes use of the collaborative nature of a wiki with (groups of) students producing argumentations either in favour or against preset propositions and mutually rate the quality of their argumentations. The teacher initiates a game by drawing up a proposition linked with a chosen domain of study. The Argument game (Figure 1) then uses four rounds:

- In round 1, the learners (in teams) write a short essay on the proposition either pro or contra.

- In round 2, the teams write five arguments in favour of their position. They may strengthen their arguments by adding a link to a reference. Moreover, in one of their arguments they may use a "cheat" argument (an argument that sounds valid but is not) which gives, if convincing enough to be accepted by the opposing team, additional points.

- In round 3, the teams challenge the arguments of their opponents.

- Finally, in round 4 the teams write a final, short essay summing up their arguments.

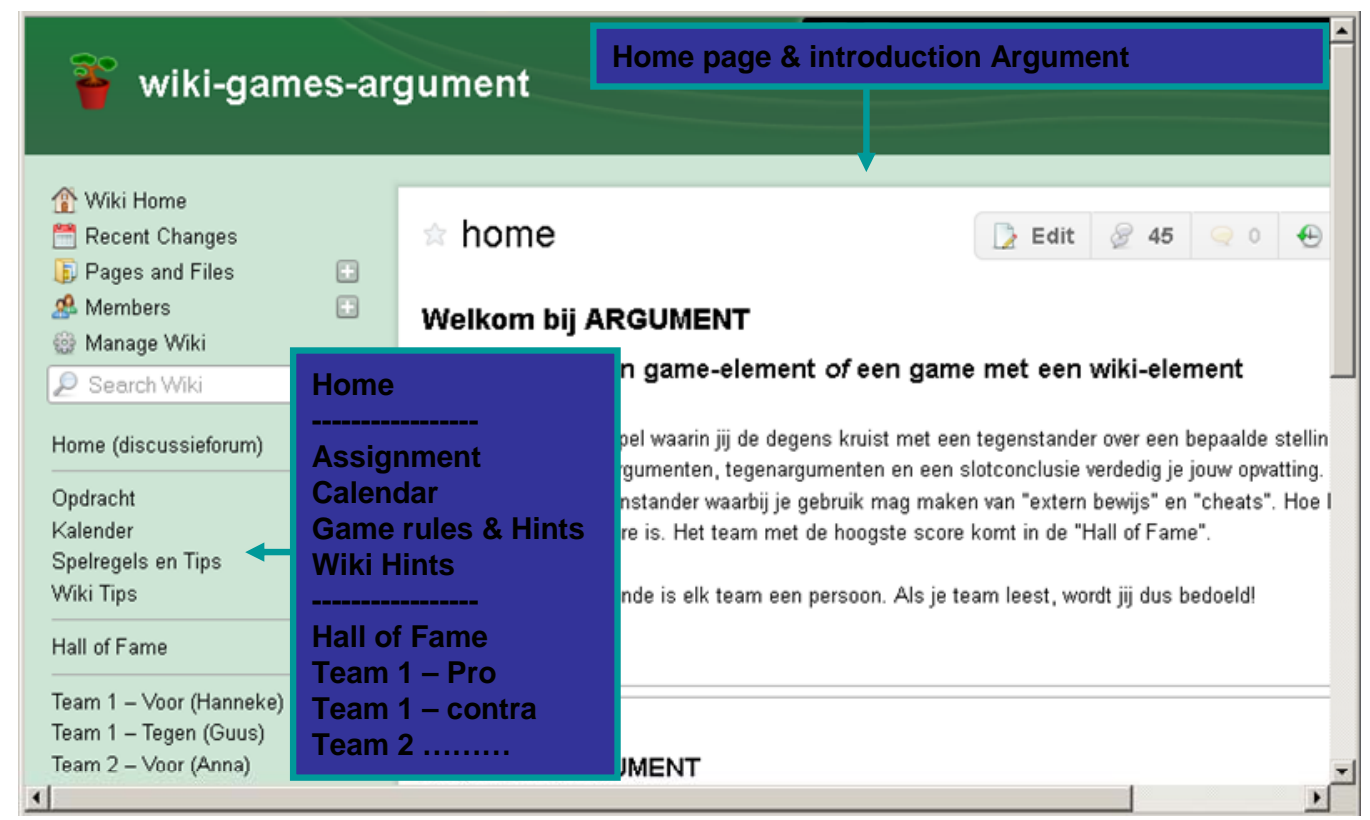

Figure 1. The home page of the wiki-game Argument with at the left its navigation panel. 
In each round a team can gain points for its contribution. A Hall of Fame is administered to show the scores. All details of the game are explained in the wiki including team compositions, position to defend or oppose, background resources, game rules, scores and scoring. Finally, each round is followed by a discussion either in a forum in the wiki or in the class room (the full details of the game including the manual are available in the game template - in Dutch - at: http://wiki-games-argumentsjabloon.wikispaces.com/).

Werk!Woord! (Bronk \& Van Rosmalen, submitted) is a wiki-game that can be used to apply and to exercise with Dutch verb spelling algorithms. It aims to improve Dutch verb spelling skills and knowledge (in terms of correct use of given spelling algorithms). The algorithms used are part of the method "Taaljournaal" (Fourdraine et al., 2007). Before the start of the game the learners receive instruction on the algorithms in their classroom. The game should stimulate the learners to actually apply and therewith learn them. The game is played in teams of two learners who according to their level should be able to cooperate effectively. The teams can collect points in a number of tasks. The team that collects the most points will be the verb-spelling-champion. Each team receives the following assignment:

1. Think of and prepare six sentences with your team. Make one sentence with a misspelled verb. Your counter team will have to discover your mistake.

2. Discover the false sentence of another party given to you and explain why that sentence is wrong and the other sentences are right. You should use the Verb Algorithm Guide (a graphically depicted decision table that if followed and applied correctly gives the right spelling) for your explanations.

The game is played in three rounds. In each round, each team has the same assignment. At the end of each round, points are distributed:

- A team gets points if it did detect the wrong sentence of their counterpart;

- A team gets points if it can explain the sentences of their counterpart according to the Verb Algorithm Guide;

- A team gets points deducted if the team accidentally made an additional error in their sentences or if it did not make a wrong sentence.

A "Hall of Fame" shows the teams with the highest score. The winning team is the Werk!Woord! Champion and wins the Werk!Woord! 'trophy'.

The game is played in three rounds. This combines the requirement to fit it into the available time in the school's lesson plan and to have additional tension in the game; i.e. to compete for the highest overall position or to be the winner of a round. Support from the Verb Algorithm Guide is gradually reduced. Round 1 offers the complete Verb Algorithm Guide with all the decision steps whereas in round 3, the steps have to be entered by the learner themselves.

\section{Methods}

In study 1 (Argument), fifteen students participated. They volunteered following an open call for participation. The majority of these students, ranging in age from 24-54, have regular jobs as teachers in schools. Study 1 consisted of two separate experiments. In part 1, the participants evaluated an instantiation of Argument as a learner. In part 2, seven of the participants continued as a teacher and designed their instantiation of Argument. In part 1, the activities were planned in a three weeks period following a strict schedule (who, what and when). For part 2, the students were free in their planning. The following data was collected: (a) the contributions to a forum which included discussions on the use of and experience with Argument (part 1); (b) progress information as compared to the schedule 
(part 1); (c) a questionnaire on the background of the participants, their participation in and opinions of part 1 and part 2; (d) the designs created by the participants (part 2).

Study 2 (Werk!Woord!) took place in group 8 of a primary school, the final group of primary education. The number of learners was 12. Each week one round was played. The game was part of the learner's individual task assignments and accordingly they had to plan their work themselves. The game started with an explanation of the game in the class room. The experiment was set up as a preexperimental study. It started with a pre-test, followed by a three week period in which Werk!Woord! was used and ended with a post-test. The experiment including the tests, scoring and observations was conducted by the first author. Additionally, at the end the learners received a questionnaire with questions on their background, and their experience with and appreciation of the game.

\section{Results}

The results demonstrate that a wiki is an appropriate tool for developing game-like activities that are motivating and fit well also for complex tasks. In more detail the outcomes are as follows.

- Is it feasible at all to create appropriate and representative game scenarios in a wiki?

Both Argument and Werk!Woord! do more or less follow all aspects as mentioned in commonly used definitions of serious games. Nadolski et al. (2006): "Multi-user online serious games are (mostly) competitive, situation-dependent, interactive digital (learning) environments based on a set of rules and / or an underlying model, which, subject to certain restrictions, under uncertainty, a challenging (learning) goal is being pursued for which cooperation is essential". The two games do follow game principles (Pernin, Michau, Mandran \& Mariais, 2012) such as competition (between two teams and all teams), individual challenge (to detect errors and to create not-easy-to-spot errors or to create or oppose arguments), collaboration (teams in which the members challenge each other to come up with the best not-easy-to spot-error or the best argument), recognition by others (by the opposing team and by all teams), and chance (players who are good in spelling have an advantage nevertheless 'winning' even for the best in spelling player or team is not guaranteed, the same applies for the best arguments). Nevertheless, when asked many of the users (Argument 54\%, Werk!Woord! 50\%) do not perceive them as a game. This is partly because the wiki-games do not meet the expectations raised by commonly used games (graphics and immersiveness) and partly as some of the Werk!Woord! users testify: "since you learn something of it" or "because it is an assignment". Overall, it can be concluded that wikis can be used to create game scenarios. Be it that wiki-games are probably best described by stating that they make use of game elements, in other words they more align with gamificiation (Raymer, 2011: http://en.wikipedia.org/wiki/Gamification: "Gamification is the use of game design techniques and mechanics to solve problems and engage audiences").

- Is there any learning and/or motivation effect?

Within the limitations of the set-up of both studies, the wiki-games were successful. For Argument the majority of the learners were neutral or negative about the motivational aspect. This was mainly due to the problems with the synchronisation of the activities due to the irregular availability of the colearners. Nevertheless, they judged Argument as a good and instructive work format (70\%) and they acknowledged that their involvement with Argument had a clear, positive effect on their knowledge of the topic discussed (70\%). Werk!Woord! was both appreciated for its motivational and learning aspects. The learners liked to use Werk!Woord! because of the cooperation element (4 learners), the competition element (6 learners) or because you learn while you play (2 learners). Tutor observations of the learners playing the game showed that the learners were engaged in the game and collaborated well. The scores on a spelling test improved from $63 \%$ correct in a pre-test to $74 \%$ correct in a post- 
test. Even more interestingly, the explanations on how the spelling was performed also improved from $18 \%$ to $73 \%$ (or from $28 \%$ to $98 \%$ of the right answers).

- What are the teachers' and learners' experiences?

The final judgement of the participants on Argument, as a learner or as a teacher building their own wiki-game, was positive despite all the inherent limitations. A larger part of the participants indicated that Argument did inspire them to start using wikis and other (easy to use) ICT tools, as an introduction to using serious games, or use Argument or a variation of it directly. The students who built their own wiki-game confirmed that it was fairly easy not only to create a wiki-game but also to apply it in a useful manner to an educational learning context. Also Werk!Woord was experienced by most of the learners as a nice and challenging way to practice verb spelling. The observation that learners encouraged others to finish their work is not common practice. Nine out of the 12 pupils indicated that they liked Werk!Woord! and 10 out of 12 that it was instructive. Overall, there was only one drawback of using a wiki to build a game: checking the assignments and keeping the scores showed to be relatively labour intensive.

\subsection{Mastership Games for Teachers-In-Training in Higher Education, Built with an Authoring Tool for Collaboration Scripts}

Workplace learning, for instance for teachers during their classroom practice, is no longer restricted to acquiring or updating domain knowledge, but also has to deal with selecting and using this knowledge for certain problem situations in daily practice. Such learning is about acquiring competences such as information skills and media literacy, problem-solving, communication and collaboration skills, and above all critical reflection. Today's teaching professionals become lifelong learners who continuously have to face problem situations that are changing dynamically and rapidly. Serious collaboration games are considered to hold potential as more open, dynamic and flexible learning environments where such professional teaching skills could be acquired through self-determined learning with little or no direct teacher intervention. Collaboration scripts have been rarely implemented within educational games so far. They use the situated context (or authentic case) to have learners access tacit knowledge by sharing and co-creating new knowledge together (Bell, Kanar, \& Kozlowski, 2008). Collaboration scripts (Kobbe et al., 2007) are an instructional method that structures the collaboration by guiding the interacting partners through a sequence of interaction phases with designated activities and roles. One of our most important research challenges is to look for flexible and effective ways to optimizing the type and amount of structured collaboration.

We developed both a card playing and online version of the 'Mastership game' that helps students, teachers-in-training in higher education, to find solutions to some of the most prevailing practical classroom management dilemmas in a playful way, to help them become better teachers. It can be assumed that collaborating on problems first will later increase their 'professional productivity' as teachers, simply because exchanging information and looking from various perspectives will increase the quality of the individual solutions, as shown by some CSCL studies (Gunawardena, Carabajal \& Lowe, 2001; Jeong \& Chi, 2000). The specific problems of the Mastership game that are under study here deal with (multiple perspectives on) classroom management dilemmas. What should a teacher do, for instance, when a pupil continues to disturb the lesson by insulting his peers? Should the problem be resolved during the lesson, even at the risk of losing valuable time to the expense of the majority of students who are not involved in the conflict? Or should the problem be resolved after the class has been dismissed, even at the risk that disturbances will continue during the lesson. Teaching can be considered to be an exciting game, as teachers will certainly have to face unexpected situations that demand finding solutions on the fly. 
The Mastership game (Figure 2) can be played in small groups from two to six students and does not require any moderation or other intervention by teachers. After selecting their avatars, they start the group play both in the role of player (or problem owner) and of co-player (judging the way that players solve their problems). The game has a (basic, default) structure that consists of five consecutive phases, during which players discuss, elaborate and negotiate solutions to solve the problem. Communication is structured by various assignments and rules during these phases, but is possible by unstructured group chat as well. During the first phase players select three practical dilemmas, either out of a pile of twenty-four, most prevailing practical classroom dilemmas (i.e., "How to maintain control in a good way", "How to deal with negative colleagues", or "How to deal with a pupil that does not want to get coached"), or by formulating one of their own. Then each player selects the problem that is considered most important. During the second phase players draw an exploratory assignment (e.g., "Provide an exemplary experience that shows why this problem is important for you"). The elaboration is judged by the co-players until the group is satisfied. During the third phase players take turns in drawing theme cards (e.g., "professional development", "dealing with losses", or "lesson preparation") that are placed at their co-players while motivating why this theme should be further explored in combination with the chosen dilemma, until every player has received three theme cards. In the fourth phase players will negotiate and discuss which theme cards may be declined. Co-players may use jury cards and ask further questions to challenge players to further motivate their declined cards before the group agrees on the final selection. During the fifth phase players select a practical assignment to further elaborate a solution for the problem in a short advisory report.

In a recent field study, the learning effects were measured and satisfaction was questioned for nine players who played the online version and ten players who played the face-to-face version of the Mastership game. All participants were third year teachers-in-training from various domains (like foreign language or science) following the game as part of a didactics course. The participants were randomly allocated to both conditions. Results have been controlled for the effects of domain, sex and age. Results showed that the collaboration of students on classroom dilemmas can indeed be successfully facilitated by this script, and that learning results do not differ for both versions. The latter holds potential for offering online and more flexible ways of workplace learning. Especially students playing the online version reported the need for simpler structures and clearer task instruction. Optimizing the level of structure in collaboration scripts therefore appears an issue for further study, and we will need flexible and user-friendly authoring environments to facilitate this. Collaborative learning online is not easy and depends on the richness and intensity of interactions (emergence of elaborated explanations, negotiation of meanings, mutual regulation of cognitive processes) as enabled by the collaboration structure. The holy grail of CSCL is to establish environments that (in)directly favour the emergence of rich interactions, which is commonly referred to as 'design for conversation' (e.g., Dillenbourg \& Fischer, 2007).

Collaboration scripts seem to offer potential to be further adapted and examined in serious gaming research. The complexity can be further reduced and reusable design patterns could become available (Westera et al., 2008). The collaboration pattern (script) we described in this study produces code that can be instantiated in different settings and domains (where mutual regulation and various perspectives play a role).

This first study revealed that clear instruction and simple structure are especially important for online learning without direct teacher intervention. We therefore have continued our work with a comparative study differentiating high-structure (as in this version, but improved), medium-structure and lowstructure in the online Mastership game. 

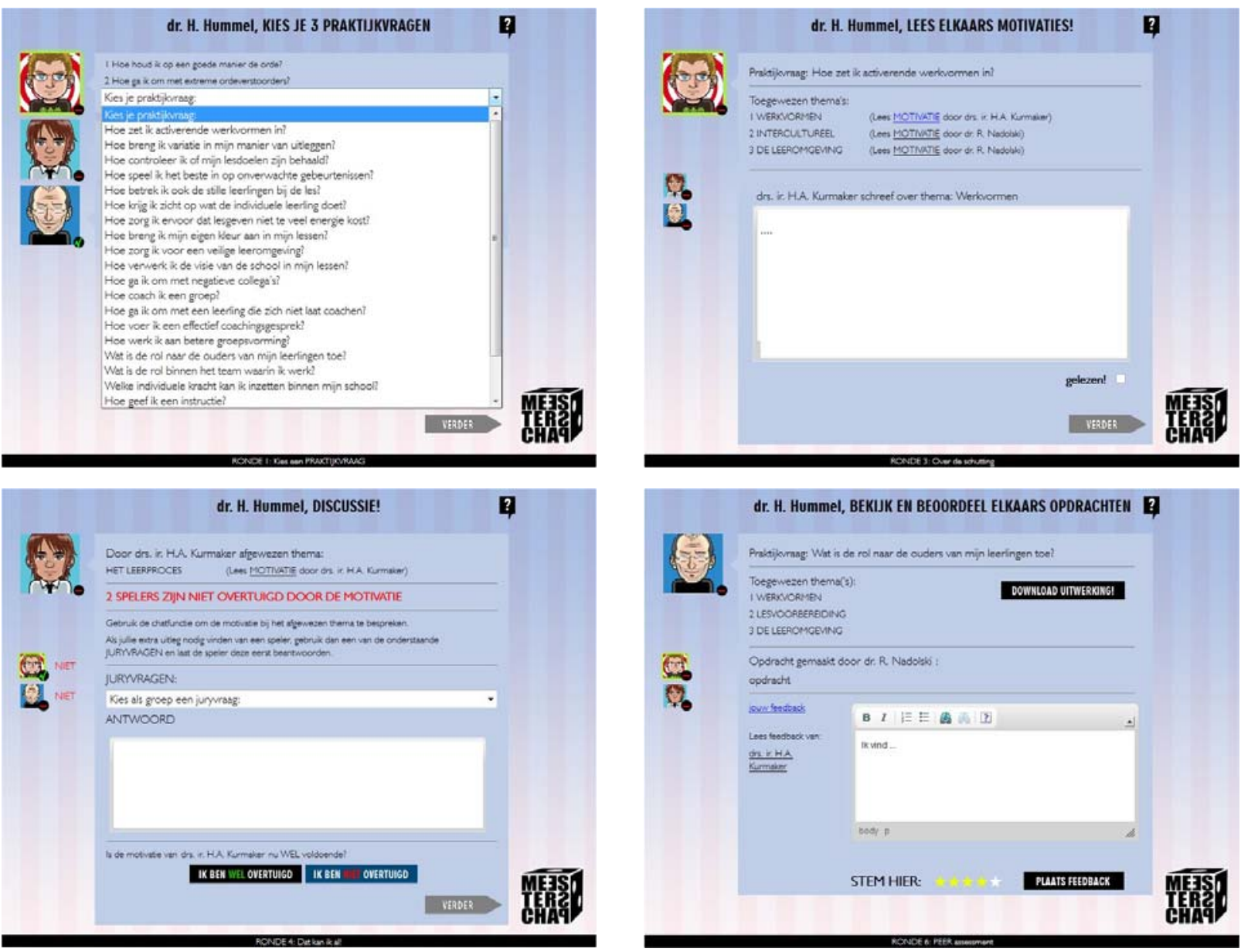

Figure 2. Screens of the online version of the Mastership game: selecting three practical dilemmas in phase 1 (upper left hand), assigning and motivating themes in phase 3 (upper right hand), motivating and discussing declined themes in phase 4 (lower left hand), and peer assessment of elaborated assignments in phase 6 (lower right hand).

The basis of defining a flexible authoring environment for defining the optimal structure of the collaboration script was to determine the elements that constitute the structure of the game play (A) or the mutual-dependency of the players (B). Preferably the nature of such elements is generic for all collaboration scripts and not specifically related to mastership. We decided to differentiate the following more or less generic structure elements:

- A1: the number of scenes in a phase (or round). Combining scenes signifies that players can move more freely within a phase, thus facing a lower structure.

- A2: the number of 'cards' that are to be drawn obligatory. If players are allowed to draw less than three or just one card in a phase obviously the structure becomes lower.

- B1: the order in which players proceed might be by taking turns or to work in parallel, with the later obviously being less dependent and facing a lower structure.

- B2: the way players may decide to move to a next scene or phase can be either by group consent or by individual choice, with the later obviously being less dependent and facing a lower structure.

- B3: the way players receive their 'cards' could be either by being drawn by others for them or by drawing the cards themselves, with the later obviously being less dependent and facing a lower structure. 
We would like to stress that this is by no means the only or best differentiation imaginable, we could think of other elements as well. However, the approach to differentiate elements as 'handles' to be turned on/off in an authoring environment seems useful, and we provide our choices as an example. Based on these structure elements, we defined a high, medium and low level of structure (Table 2).

Table 2. Structure table.

\begin{tabular}{|l|l|l|l|l|l|}
\hline & A1 & A2 & B1 & B2 & B3 \\
\hline High & True & 3 & True & True & True \\
\hline Medium & False & 1 & False & True & True \\
\hline Low & False & 1 & False & False & False \\
\hline
\end{tabular}

We have currently implemented these three levels of structure following this approach, have partially carried out a second field study comparing these versions of structure with actual students, and are in the process of completing the setup and data collection.

Besides looking into the effects of optimizing structure, and the role the authoring environment can play to facilitate this optimization by teachers themselves, we also intend to look how to generalize the findings. Dillenbourg \& Hong (2008) propose script families as a higher level of abstraction that discriminate classes of scripts that use the same pattern, e.g., JigSaw (distributing knowledge among group members), ArgueGraph (raising a conflict pattern), or Reciprocal Teaching (using mutual regulation). The Mastership game belongs to the latter family, but it might be useful to explore others, as we have already successfully implemented and studied a conflict script in a game on water management (Hummel et al., 2011) whose narrative and collaboration script were described in the second section of this article. We also plan to implement Argument scripts (Van Rosmalen \& Westera, 2012) in the collaboration scripting environment.

Finally, related to this and similar case studies that relate to collaboration on complex problems, structure is a highly important but not sole variable that should be adjustable in a flexible authoring environment for teachers. There are other variables in a serious game play that will have to be conceived, researched, and potentially included in the authoring environment we currently are working on, such as the following:

- Problem quality. In the current studies we used 'cards' with a short description of a dilemma to be discussed and collaborated upon. Based on this description every player had to visualize and enrich this description by relating it to personal knowledge and experience. It might well be that personal experience is a stronger determinant for effective game play than the quality of the collaboration script and game play. It might be interesting to look into 'richer' case descriptions, for instance by using videos with teachers talking about dealing with classroom dilemmas, as available in the Didiclass video database (Geerts, Mitzschke \& Van Laeken, 2009). Their usage and added value is planned to be studied in a subsequent study.

- Modality. In the current studies we used verbal information on cards. Students verbally exchanged information without receiving non-verbal cues about the conversation or cases. It might be useful to present audiovisual cases as suggested in the previous aspect (or even virtual worlds in which the cases are situated), or have audiovisual communication possibilities. For instance using technologies like bio-sensors to input information about co-players' stress level or language technologies to interpret communication automatically might increase the realism of the collaboration process.

- Roles. The differentiation of roles was relatively simple in the Mastership game, players were either player / problem owner or co-player / judge of others' problem elaboration. It might be interesting to 
look at collaboration scripts were players assume various roles or perspectives, as we described in the Aquaculture example in section 2.

- Synchronicity. In the current studies players to a large extent had to collaborate synchronously; only the individual elaboration of the assignment could be executed asynchronously. It appears complicated to synchronise the collaboration in a way without unwanted delay for some of the players because patterns of work differ. It might be interesting to further explore the optimal balance between synchronous and asynchronous parts of the collaboration scripts.

\section{GAMES FOR AND BY LEARNERS}

Continuing on from games by teachers, we will now discuss a case study of a tool, Scratch, which has been designed to be used by learners. As discussed above, to have students make their own computer applications is already a relatively old application. Moreover, since most of the current generation of students are very familiar with games, it should fit very well with their interests to have students develop their own games and have them experience what it is to design and develop a game.

\subsection{Scratch}

Logo (Papert, 1980) was the program that inspired Scratch. It is a visual-based tool and children are encouraged to create programs by simply snapping together the blocks provided to create their own program or script as it is known in Scratch. Figure 3 shows example screens shots of Scratch.
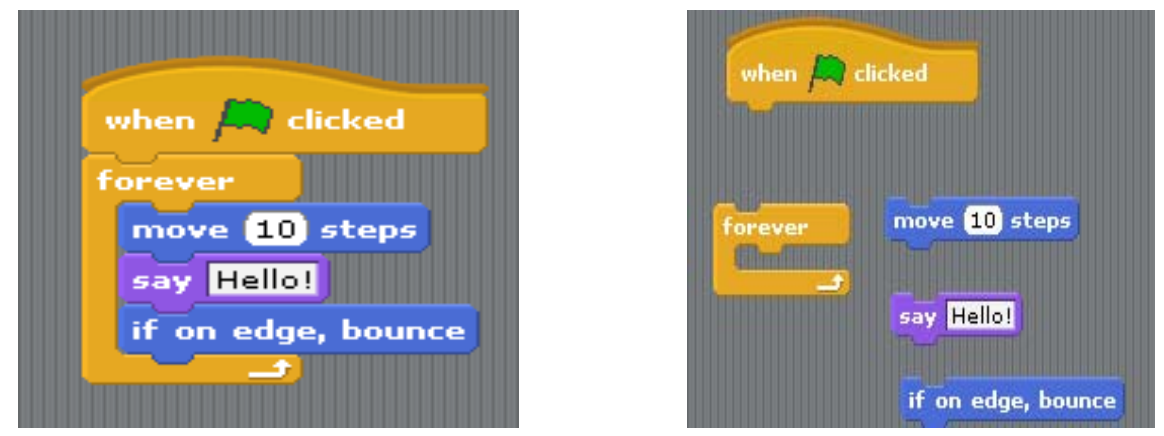

Figure 3: Example screenshots of Scratch

Scratch is primarily aimed at children aged around eight, however, statistics from the Scratch site show that the average age of users is 12 (MIT, 2011) and there is a wide age range of users for this tool. It was envisaged from the outset that while this project was to introduce computers to deprived areas eventually the informal educational benefits of it would be studied at a later date (Resnick, Kafai \& Maeda, 2003). Although Scratch has been used in formal education (Malan \& Leitner, 2007; Malan, 2010), there is currently little published research on whether Scratch can be used as a tool for teaching programming concepts in a primary classroom setting. Research has focused on the community around Scratch that has been built up since its introduction. Brennan, Resnick and Monroy-Hernández (2010) discuss how Scratch is used by the online Scratch community with participants ranging from socialisers through to creators of projects while Monroy-Hernández and Resnick (2008) discuss the collaborative nature of the community and how groups of users are starting to set up their own "miniature companies" to produce games of high quality.

There is currently little published research on what learning takes place when constructing games with Scratch in a primary classroom setting (Hayes \& Games 2008). Adams (2010) looked at the use of Scratch during a five day summer camp with 30 boys and 15 girls aged 13 and above. The children were given the chance to create either multimedia videos or games with Scratch and out of the 45 children who attended only 3 did not make games. The children all reported that they thoroughly 
enjoyed working with Scratch with the girls scoring the camp either very good or good on their opinions of their camp enjoyment. While Sivilotti and Laugel (2008) undertook out-of-school workshops with 13-14 year olds to gauge their opinions on Scratch, studies such as Maloney et al. focus on what blocks the children had used over an extended period of time in their Scratch projects during an after-school computer clubhouse.

Within educational establishments and during lesson time, projects such as those described by Wilson, Connolly, Hainey and Moffat (2011) show how Scratch can be used with young children aged 8-9 to learn programming concepts through the introduction of game making. Children were given 8 lessons to introduce them to programming and also to gauge how much they enjoyed working with Scratch. Baytak and Land (2011) in their study focused on learning by design where 10 to 11 year old children planned and designed and then created their game with Scratch during a science project. At Harvard University Scratch has been used as an introduction to programming for new undergraduate students (Malan \& Leitner, 2007; Malan, 2010). This entailed students developing Scratch projects as part of the introductory lessons to introduce programming concepts to help prepare them for using Java.

\subsection{Scratch: Programming \& Design in the ICT Curriculum}

The Scottish Government has reviewed the Scottish curriculum over the past few years and, after much consultation, a new Curriculum for Excellence (CfE) has been implemented within Scottish schools (Scottish Executive, 2006). This reform of education is one of the biggest Scotland has seen and intends to give a coherent curriculum for children from 3 years through to 18 years (Scottish Executive, 2008). Teachers should also be taking the opportunities given in using Information and Communications Technology (ICT) for more interdisciplinary learning (HMIE, 2009). Within the CfE teachers are being encouraged to make more use of different styles of approaches to learning as well as interdisciplinary work, one of which is the use of ICT within learning. ICT as an approach to learning is being encouraged to develop children's digital literacy skills and some suggested means of implementing this are through the use of Glow - the Scottish schools' intranet system - or gamesbased learning (GBL) (LTS, 2011a), which is supported by the Consolarium (LTS, 2011b), an initiative set up by Education Scotland to support teachers in exploring the use of GBL in their class. This is further enhanced within the Technologies curricular area that looks for children to be making use of games through designing and creating their own games.

A pilot study of the use of Scratch was conducted within a Primary School in Glasgow. 60 children in 3 classes ( 27 girls and 33 boys) aged between 8 and 11 participated. The classes comprised of primary 4 that had 18 children; primary 5/6 that had 20 children and primary 6/7 that had 22 children. The children worked in the same pairs throughout the project: 7 pairs of boys, 5 pairs of girls, one group of 3 boys, one group of 2 boys and 1 girl and 16 boy/girl pairs.

The aim of the pilot study was to introduce Scratch into the primary ICT curriculum by way of eight lessons focusing introducing programming concepts though game construction. The games would then be evaluated at the end of the study to show what programming skills the children used within the games they created.

Over the course of eight weeks the children were given a one hour lesson with Scratch with the principle investigator leading the lessons alongside the class teacher. They were structured so that for the first few weeks the principal investigator spoke for the first 5 minutes of the lesson to explain the work and then the children worked in pairs on their computers on their games. Towards the end of the project the children were able to start lessons straight away on the computers to keep working on their games. During lessons when children were on the computer they were working in pairs, this was in part due to the limited resources of the school; however, collaborative work is actively encouraged 
within the CfE. The class teacher was also actively encouraged to help and become more involved in the work as the weeks progressed. Through this work it is envisaged that the class teachers themselves will then go on to teach future classes game construction with Scratch. The lessons were planned to introduce the basic concepts of programming to children as detailed by Rusk (2009a). Given the short timeframe a selection of the concepts were focused upon namely:

- Sequence

- Iteration

- Conditions

- Coordination and Synchronisation.

As well as looking at the programming concepts children were going to be taught, it was important to match the lessons to CfE guidelines (LTS, 2009) in order for the class teachers to see how they are able to easily incorporate the use of game construction within their lessons. While the main focus was on "Using appropriate software, I can work collaboratively to design an interesting and entertaining game which incorporates a form of control technology or interactive multimedia" (LTS, 2009) the following outcomes were also used:

1. I can create, capture and manipulate sounds, text and images to communicate experiences, ideas and information in creative and engaging ways.

2. Having evaluated my work, I can adapt and improve, where appropriate, through trial and error or by using feedback.

3. Through discovery, natural curiosity and imagination, I explore ways to construct models or solve problems.

4. I explore software and use what I learn to solve problems and present my ideas, thoughts, or information.

Over the 8 lessons the children were first given an introduction to Scratch then shown how to make a simple maze game (see Figure 4) before finally creating their own game. Table 3 gives a breakdown of the lesson plan.

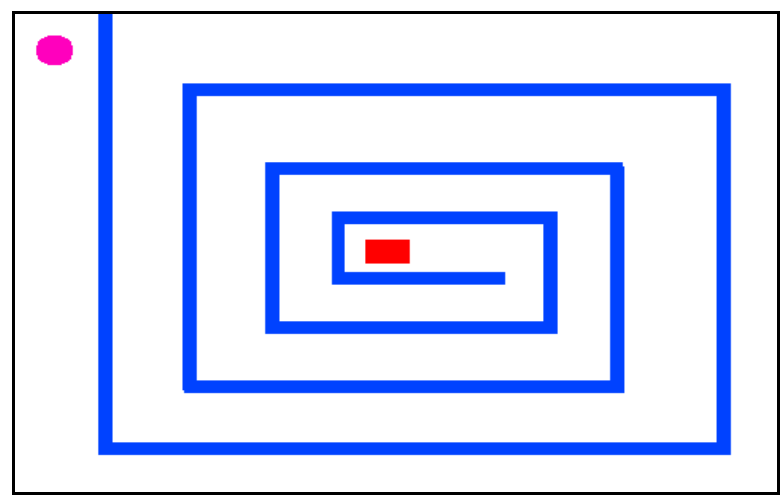

Figure 4. Simple maze game. 
Games For and By Teachers and Learners to appear in Connolly, T.M., Boyle, E., Hainey, T., Baxter, G. \& Moreno-Ger, P. (Eds) Psychology, Pedagogy and Assessment in Serious Games.

Table 3: Lessons given in class.

\begin{tabular}{|l|l|l|}
\hline Week 1 & $\begin{array}{l}\text { Lesson } \\
\text { Scroduction to Scratch using }\end{array}$ & $\begin{array}{l}\text { Overview of lesson(s) } \\
\text { Children were given one of the twelve Scratch cards to } \\
\text { work on. Once completed they were able to change cards } \\
\text { and work their way through the set. }\end{array}$ \\
\hline Weeks 2-4 & $\begin{array}{l}\text { Constructing a simple maze } \\
\text { game (Brennan, 2009) with a } \\
\text { timer }\end{array}$ & $\begin{array}{l}\text { The children were given instructions in how to construct a } \\
\text { basic maze game with one sprite and one background. They } \\
\text { were shown how to control the sprite through the maze } \\
\text { using the arrow keys. Finally, they were then shown how to } \\
\text { add a timer and scoring to their game to increase the } \\
\text { challenge. }\end{array}$ \\
\hline Weeks 5-8 & $\begin{array}{l}\text { Constructing own game in } \\
\text { Scratch }\end{array}$ & $\begin{array}{l}\text { Children were able to continue their game construction } \\
\text { either by making adaptations to the maze game they had } \\
\text { been working on during the previous weeks or by } \\
\text { constructing a new game by themselves. }\end{array}$ \\
\hline
\end{tabular}

\subsection{Concepts within Games}

A coding scheme was adapted from the scheme created by Denner, Werner and Ortiz (2012) and refined based on the programming concepts that could be learned with Scratch (Rusk, 2009a).

Table 3: Game coding categories and definitions.

\begin{tabular}{|c|c|c|}
\hline \multicolumn{2}{|c|}{ Programming concepts found in Scratch } & \multirow{2}{*}{$\begin{array}{l}\text { Coding } \\
0 / 1\end{array}$} \\
\hline 1. Sequence & Are the blocks in a systematic order to execute the program correctly? & \\
\hline 2. Iteration & Using forever and repeat to create iterations. & $0-3$ \\
\hline 3. Variables & $\begin{array}{l}\text { Variables can be created within Scratch and then be used within } \\
\text { programs. }\end{array}$ & $0-3$ \\
\hline $\begin{array}{l}\text { 4. Conditional } \\
\text { Statements }\end{array}$ & Using if, forever if and if-else to check for conditions. & $0-3$ \\
\hline 5. Lists (arrays) & Allows for storing and accessing lists of strings and numbers. & $0 / 1$ \\
\hline 6. Event handling & Responding to events triggered by either the user or another script. & $0-2$ \\
\hline 7. Threads & $\begin{array}{l}\text { Launching two independent scripts at the same time to execute in } \\
\text { parallel. }\end{array}$ & $0-2$ \\
\hline $\begin{array}{l}\text { 8. Coordination and } \\
\text { Synchronisation }\end{array}$ & $\begin{array}{l}\text { Using blocks such as wait, broadcast and when I receive to coordinate } \\
\text { the actions of multiple sprites. }\end{array}$ & $0-3$ \\
\hline 9. Keyboard Input & Using blocks such as ask and wait prompts users to type in an answer. & $0-2$ \\
\hline 10. Random Numbers & Pick Random is used to select random integers within any given range. & $0 / 1$ \\
\hline 11. Boolean Logic & Using and, or, not. & $0 / 1$ \\
\hline $\begin{array}{l}\text { 12. Dynamic } \\
\text { Interaction }\end{array}$ & $\begin{array}{l}\text { Using mouse } \mathrm{x} \text { or } \mathrm{y} \text { and loudness can be used as dynamic input for } \\
\text { interaction. }\end{array}$ & $0 / 1$ \\
\hline $\begin{array}{l}\text { 13. User Interface } \\
\text { Design }\end{array}$ & $\begin{array}{l}\text { Using when sprite clicked button can create an interactive user } \\
\text { interface. }\end{array}$ & $0 / 1$ \\
\hline \multicolumn{2}{|l|}{ Code organisation } & \\
\hline 14. Extraneous blocks & Are there any blocks which are not initialised when the program is run? & $-1 / 0$ \\
\hline
\end{tabular}


Games For and By Teachers and Learners to appear in Connolly, T.M., Boyle, E., Hainey, T., Baxter, G. \& Moreno-Ger, P. (Eds) Psychology, Pedagogy and Assessment in Serious Games.

\begin{tabular}{|l|l|l|}
\hline $\begin{array}{c}\text { 15. Sprite names (the } \\
\text { default is } \\
\text { overridden). }\end{array}$ & Are the default sprite names overridden? & $0 / 1$ \\
\hline \multicolumn{1}{|c|}{ 16. Variable names } & Are the variables given meaningful names when set up? & $0 / 1$ \\
\hline Designing for usability & $\begin{array}{l}\text { Does the game run when it is started (most games start when the green } \\
\text { flag is clicked)? }\end{array}$ & $0-3$ \\
\hline $\begin{array}{l}\text { 17. Functionality } \\
\text { 18. Goal }\end{array}$ & Is there a clear defined goal to the game? & $0-2$ \\
\hline $\begin{array}{l}\text { 19. Sprite } \\
\text { customisation }\end{array}$ & $\begin{array}{l}\text { Is the sprite used a predefined sprite or has the sprite been customised } \\
\text { and to what extent. }\end{array}$ & $0-3$ \\
\hline $\begin{array}{l}\text { 20. Stage } \\
\text { customisation }\end{array}$ & $\begin{array}{l}\text { Is the stage used a predefined stage or has the stage been customised } \\
\text { and to what extent. }\end{array}$ & $0-3$ \\
\hline 21. Instructions clear & Has the student defined how the game is supposed to run? & $0-3$ \\
\hline $\begin{array}{l}\text { 22. Game originality } \\
\text { Students were asked to create a maze game to give them the grounding } \\
\text { in basic skills that were required. However when it came to creating } \\
\text { their own game students were able to adapt the maze game or create a } \\
\text { new game entirely. }\end{array}$ & $0-3$ \\
\hline
\end{tabular}

The 29 games that were constructed by the students varied in their complexity. Games ranged from adaptations of the maze game that included two player versions to original games like pair 17's two player game, which had player 1 being the fox and player 2 the box. The aim of this game was for player 1 to reach the bush on the other side while trying to get past player 2 and also before the time ran out (see Figure 5). This game scored well on originality although the pair had used a pre-made sprite instead of designing their own for the fox. However, this was the only element of the game not designed by the pair.

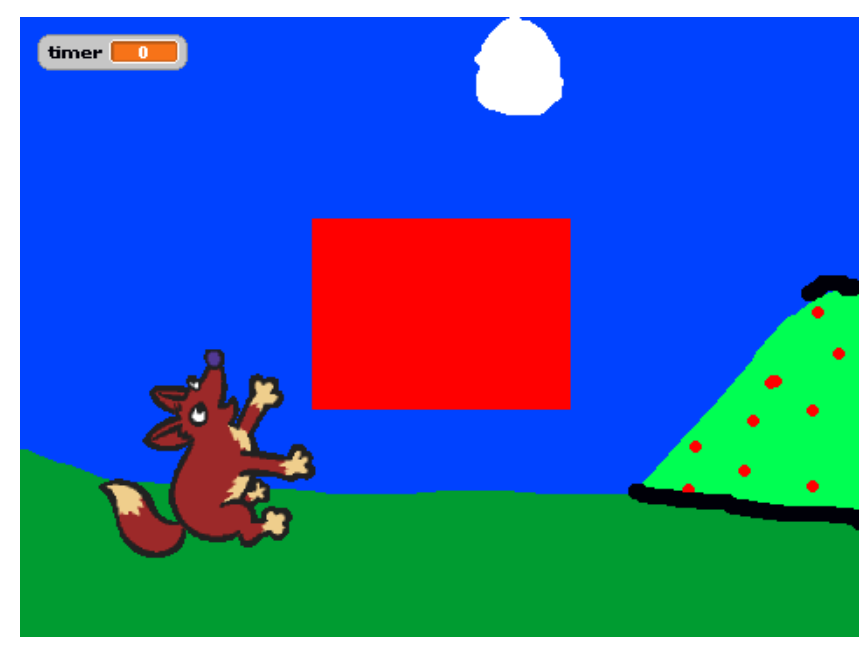

Figure 5. Pair 17's two player original game.

The only game from the 29 to use mouse control was one created by pair 7 in the Primary 4 class (Figure 6). The game was a join the dots game where the aim of the game was for the player to click on a dot then draw round the shape shown on screen. 

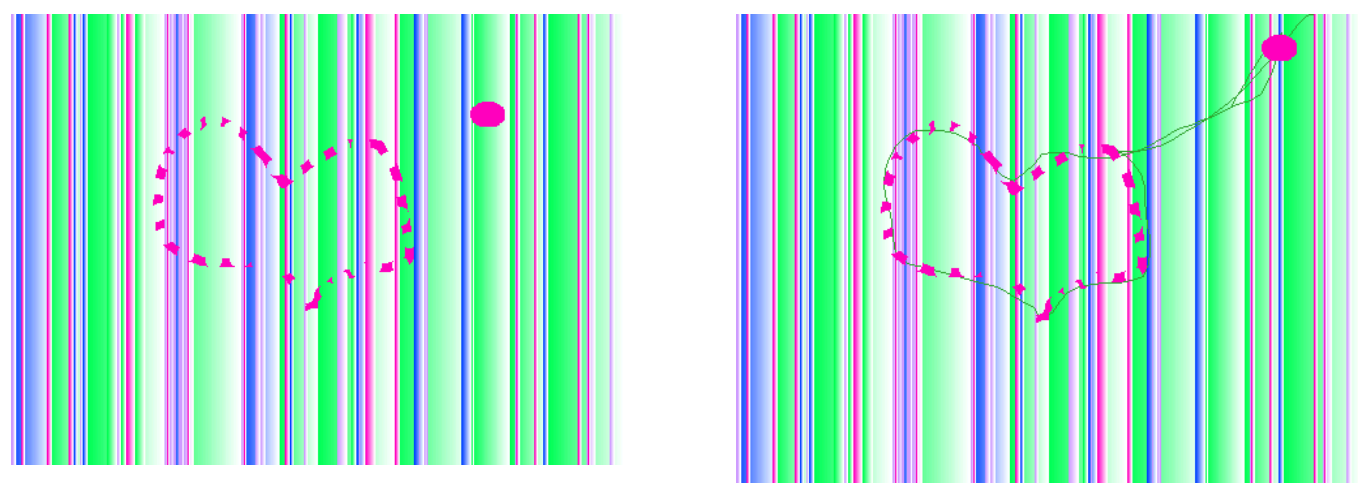

Figure 6 shows start and end of pair 7's join the dots game.

This used functionality in Scratch that was influenced by Logo as the player can direct a pen to move up and down or, in this case, when the game starts the pen is put down and follows the mouse. Another game that did not use functionality through using keys to move the sprite was a game by pair 15 in the P5 class. This game used a series of questions asked to the player who would have to type the answer in (see Figure 7) and the sprite would progress across the screen if they got the correct answer. If they got a wrong answer a sound would play and they would be told "game over". This game was different from the other games as only one script was used for the whole game. The pair used nested if/else statements to control the questions (see Figure 8).

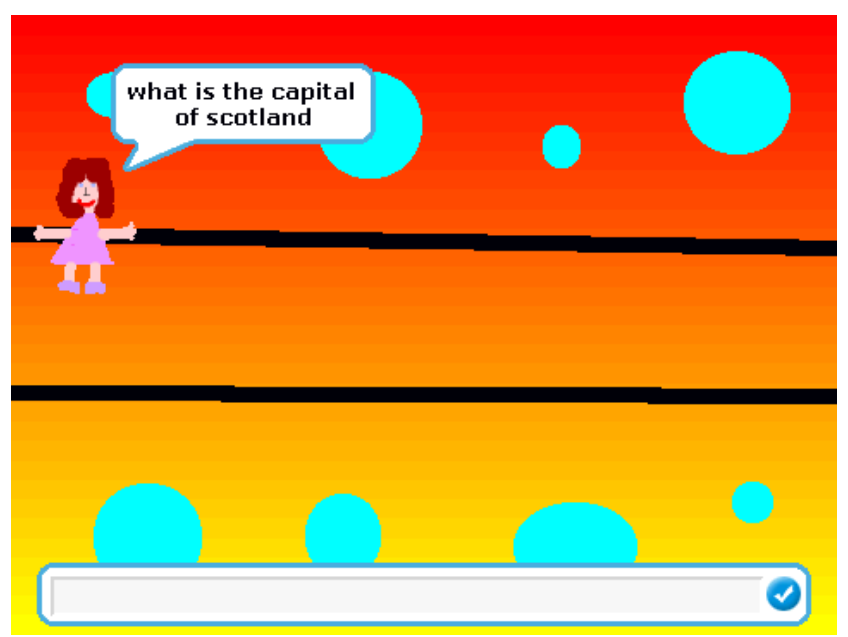

Figure 7. Pair 15's game. 


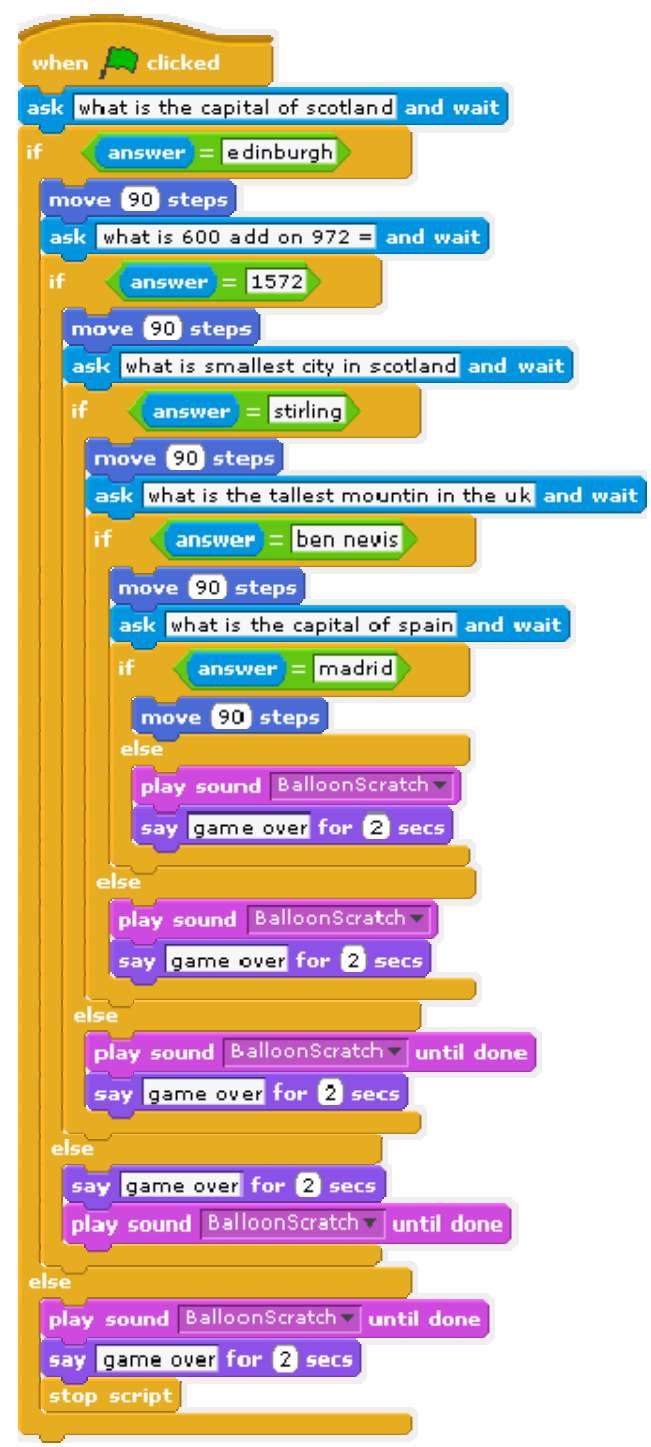

Figure 8. Script for pair 15's game.

Throughout the project the children were actively encouraged to construct their own sprites and backgrounds for their games to demonstrate their creativity. This can be seen in games where the children have thought about their characters and drawn them out. Some children, though not many, chose to work with the sprites and backgrounds that Scratch is supplied with.

There are few prior studies that look at the learning of computing concepts though game construction. While previous research has shown that children are able to learn basic programming concepts through game making projects (Denner, Werner \& Ortiz, 2012; Maloney et al., 2008) little is actually known within the primary classroom setting (Wilson, Connolly, Hainey \& Moffat, 2011).

An important limitation within the study was the amount of time given to covering the programming concepts. The children only had a limited time with their introduction to Scratch, they also were working in groups which some children found difficult and some lessons were spent negotiating decisions on how their games were going to work, this is similar to the work of Denner, Werner and Ortiz (2012) who also found that games made may not have actually reflected what children were capable of. The eight lessons covered the basics of game making with Scratch, given the timeframe and age of children this was a basic introduction. If more time had been available then the children would have been able to progress to making more complex games and learning more programming concepts. Most groups were successful in their attempts at creating their game whether it was a maze 
game or original creation. The primary 4 class did not make as many original games as the other two classes, however, they preferred to adapt the maze game that they had created and had the most amount of games that were functional or only with minor mistakes. Both primary $5 / 6$ and primary $6 / 7$ classes had equal amounts of original games, indeed $60 \%$ of each class made their own game. However the primary $5 / 6$ class were more successful in implementing their games with more functionality than the primary $6 / 7$ class.

The most used programming concepts by children in the project were similar to those found in Maloney et al. (2008), namely User Interaction (key handling), Loops (iteration) and Conditional Statements. While gender groupings did not have a significant effect on game scores, the primary $5 / 6$ class did have the highest mean score as well as the most functional games. This class consisted of mixed gender groupings.

Overall the children did manage to gain some programming concepts over the eight week period. The study has shown that even within eight hours of lessons children were able to make progress with Scratch and their learning of programming. This was similar to the results of Baytak and Land (2011), who reported that children had completed games after 10 Scratch lessons or 6 for their experienced children, as well as being similar to the game construction work of Robertson and Howells (2008) with the Neverwinter Nights project.

Further research will entail expansion of the study to include further primary schools in the Glasgow region. This will involve inclusion of different age groups to attain further empirical results to produce more statistically significant evidence and assist in refining the instruments of evaluation through a series of pilot studies. The age groups targeted would be in the age range of eight to eleven at primary four, five, six and seven level. This will enable comparisons between the different primary school levels to ascertain the suitability of the computer game construction tool at different primary educational levels.

\section{CONCLUSION}

The objective of this chapter was to make a case and exemplify that the design and use of games in education is not necessarily the exclusive domain of game professionals or that it should be too complex to embed games in education. Starting from some very simple games that might be readily included in a lesson, we evolved to discuss game engines purposed on teachers and, finally, to games purposed on students themselves. We have only discussed a very limited sample of game tools available, nevertheless, we do think that the selection discussed is representative of what is available and have been used successfully.

The variety of the examples discussed, and in many cases the large and active communities around tools, show that serious games are within reach for teachers who are interested in using them in their lessons. Therefore we do hope this chapter will inspire teachers to build and use their own games. Hopefully, they will also realise that building a game already may be very rewarding. It is important to notice that the examples discussed clearly reveal that building games is not the exclusive domain of teachers in computer science or related domains but equally within reach for teachers in other domains. Finally, while we realise that while showing that games are within reach for teachers at the same level as social media, we have not shown how to design effective and motivating games. Therefore, we suggest teachers work together and take into account examples of best practice and (evolving) methods to design serious games. 
Games For and By Teachers and Learners to appear in Connolly, T.M., Boyle, E., Hainey, T., Baxter, G. \& Moreno-Ger, P. (Eds) Psychology, Pedagogy and Assessment in Serious Games.

\section{REFERENCES}

Adams, J.C. (2010). Scratching middle schoolers' creative itch. In Proceedings of the 41st ACM technical symposium on Computer science education. ACM, pp. 356-360.

Ayers, Ph., \& Ortega, F. (Eds) (2010). Proceedings of the 6th International Symposium on Wikis and Open Collaboration 2010. Gdansk, Poland, ACM.

Baytak, A., \& Land, S. (2011). An investigation of the artifacts and process of constructing computers games about environmental science in a fifth grade classroom. Educational Technology Research and Development. Springer Boston Vol. 59 issue 7 pp 765-782.

Bell, B. S., Kanar, A. M., \& Kozlowski, S. W. J. (2008). Current issues and future directions in simulation-based training in North America. The International Journal of Human Resource Management, 19(8), 1416-1434.

Brennan, K, Chung, M., \& Hawson, J. (2011). Scratch Curriculum Guide Draft. Retrieved January 2, 2013, from http://scratched.media.mit.edu/resources/scratch-curriculum-guide-draft

Brennan, K., Resnick, M., \& Monroy-Hernández, A. (2010). Making projects, making friends: Online community as a catalyst for interactive media creation. New Directions for Youth Development, 2010 (128), 75-83.

Brennan, K. (2009). Maze Game. Retrieved September 5, 2011, from: http://scratched.media.mit.edu/resources/lets-play

Bronk, S., \& Van Rosmalen, P. (submitted). Learning Dutch Verb Spelling through a Simple, Yet Powerful, Wiki-Game.

Chou, L. D., Liu, T. C., Li, D. C., Chen, Y. S., Ieong, M. T., Lee, P. H., \& Lin, Y. C. (2011). Development of a Game-based Learning System Using Toy Robots. In Proceedings of the 2011 IEEE 11th International Conference on Advanced Learning Technologies (pp. 202-204). IEEE Computer Society.

De Freitas, S. (2006). Learning in immersive worlds. A review of game-based learning. London: Jisc. Retrieved August, 24, 2012, from http://www.jisc.ac.uk/media/documents/programmes/elearninginnovation/gamingreport_v3.pdf

Denner, J., Werner, L., \& Ortiz, E. (2012). Computer games created by middle school girls: Can they be used to measure understanding of computer science concepts? Computers \& Education, Volume 58, Issue 1, January 2012, 240-249.

Dillenbourg, P., \& Fischer, F. (2007). Basics of computer-supported collaborative learning. Zeitschrift für Berufs- und Wirtschaftspaedagogik, 21, 111-130.

Dillenbourg, P., \& Hong, F. (2008). The mechanics of CSCL macro scripts. International Journal of Computer-Supported Collaborative Learning, 3(1), 5-23. Springer.

FAS (2006). Harnessing the Power of Video Games for Learning. Summit of educational games. Washington DC, Federation of American Scientists.

http://www.fas.org/gamesummit/Resources/Summit\%20on\%20Educational\%20Games.pdf

Fischer, G., \& Kling, U. (1974). LOGO - Eine Programmiersprache für Schüler; Inhaltliche und Methodische Aspekte ihrer Anwendung. Proceedings "Rechner-gestützterUnterricht", Lecture Notes in Computer Science, Vol. 17, 1974, pp. 290-299. 
Games For and By Teachers and Learners to appear in Connolly, T.M., Boyle, E., Hainey, T., Baxter, G. \& Moreno-Ger, P. (Eds) Psychology, Pedagogy and Assessment in Serious Games.

Fourdraine, A., Hotho, H., Janssen, D., Janssen, K., Maters, A., Munsterman, D., Pijl, J., Van der Veen, S., \& Van der Vereijken-Jonkers, S.M. (2007). Taaljournaal. ‘s-Hertogenbosch: Malmberg.

Geerts, W., Mitzsche, M., \& Van Laeken, M. (Red.). (2009). Wat zou je doen? Dilemma's in de onderwijspraktijk. Bussum: Coutinho.

Gunawardena, C.N., Carabajal, K., \& Lowe, C.A. (2001). Critical Analysis of Models and Methods used to evaluate Online Learning Networks. Seattle: AERA.

Hayes E.R., \& Games I.A. (2008). Making computer games and design thinking: a review of current software and strategies. Games and Culture, 3 (3-4) (July 2008), 309-332.

HMIE (2009). Improving Scottish Education, HMIE, Scotland.

Hummel, H.G.K., Van Houcke, J., Nadolski, R.J., Van der Hiele, T., Kurvers, \& Löhr, A. (2011). Scripted collaboration in serious gaming for complex learning: Effects of multiple perspectives when acquiring water management skills. British Journal of Educational Technology, (42)6, 1029-1041.

Hummel, H.G.K., Geerts, W.M., Slootmaker, A., Kuipers, D., \& Westera, W. (in press). Collaboration scripts for mastership skills: Online game about classroom dilemmas in teacher Education. Interactive Learning Environments.

Jeong, H., \& Chi, M.T.H. (2000). Does Collaborative Learning Lead to the Construction of Common Knowledge? Retrieved July 9, 2004, from: http://www.ircs.upenn.edu.edu/cogsci2000/PRCDNGS/SPRCDNGS/posters/jeo_chi.pdf

Klopfer, E., Osterweil, S., \& Salen, K. (2009). Moving Learning Games Forward, Obstacles Opportunities \& Openness, Cambridge MA: MIT/The Education Arcade. Retrieved from http://education.mit.edu/papers/MovingLearningGamesForward_EdArcade.pdf

Kobbe, L., Weinberger, A., Dillenbourg, P., Harrer, A., Hämäläinen, Häkkinen, P., \& Fisher, F. (2007). Specifying computer-supported collaboration scripts. Computer-Supported Collaborative Learning, 2, 211-224.

LTS (2009). Curriculum for Excellence: Technologies Experiences and Outcomes.

LTS (2011a). Approaches to learning [Online]. Retrieved January 28, 2012, from: http://www.ltscotland.org.uk/learningteachingandassessment/approaches/index.asp

LTS (2011b). The Consolarium [Online]. Retrieved January 28, 2012, from: http://www.ltscotland.org.uk/usingglowandict/gamesbasedlearning/consolarium.asp

Malan, D. J. (2010). Reinventing CS50. In Proceedings of the 41st ACM technical symposium on Computer science education. ACM, 152-156.

Malan, D. J., \& Leitner, H. H. (2007). Scratch for budding computer scientists. In Proceedings of the 38th SIGCSE technical symposium on Computer science education. ACM, 223-227.

Maloney, J. H., Peppler, K., Kafai, Y.B., Resnick, M., \& Rusk, N. (2008). Programming by choice: urban youth learning programming with scratch. In Proceedings of the 39th SIGCSE technical symposium on Computer science education. ACM, 367-371.

MIT (2011). Statistics on scratch users. Retrieved May 5, 2011, from: http://stats.scratch.mit.edu/

Monroy-Hernández, A., \& Resnick, M. (2008). Empowering kids to create and share programmable media. Interactions 15, 2 (March 2008), 50-53. 
Games For and By Teachers and Learners to appear in Connolly, T.M., Boyle, E., Hainey, T., Baxter, G. \& Moreno-Ger, P. (Eds) Psychology, Pedagogy and Assessment in Serious Games.

Nadolski, R.J., Van der Hijden, P., Tattersall, C., \& Slootmaker, A. (2006). Multi-user online serious games: Beleid, ontwerp en gebruik [Multi-user online serious game: Policy, design and use]. DU TOGA. Utrecht: Stichting Digitale Universiteit.

Nadolski, R.J., Hummel, H.G.K., Van den Brink, H.J., Hoefakker, R., Slootmaker, A., Kurvers, H., \& Storm, J. (2008). EMERGO: methodology and toolkit for efficient development of serious games in higher education. Simulations \& Gaming, 39(3), 338-352.

National Gaming Survey (2009). Detailed data of gaming in the Netherlands. Newzo, TNS-NIPO. Retrieved February 24, 2012, from http://www.nationaalgamingonderzoek.nl.

NFER (2009). Teacher Voice Omnibus Survey. Retrieved August 24, 2012, from NFER: Berkshire: http://www.nfer.ac.uk/nfer/what-we-offer/teacher-voice/PDFs/futurelab.pdf

Overmars, M. (2004). Teaching computer science through game design. Computer, vol.37, no.4, pp. 81- 83, April 2004. Doi: 10.1109/MC.2004.1297314.

Papert, S. (1980). Mindstorms: children, computers, and powerful ideas, Basic Books, Inc.

Pernin, J., Michau, F., Mandran, N., \& Mariais, C. (2012). ScenLRPG, a Board Game for the Collaborative Design of Gbl Scenarios: Qualitative Analysis of an Experiment. Proceedings of the 6th European Conference on Games Based Learning. Cork, Ireland, 4-5 October 2012, pp384-392.

PWC (2010). Global Entertainment and Media Outlook: 2010-2014. Retrieved from http://www.pwc.com/.

Razak, A.A., Connolly, T..M., \& Hainey, T. (2012). Teachers'Views on the Approach of Digital Games-Based Learning within the Curriculum for Excellence. International Journal of GameBased Learning, Vol. 2, Issue 1, pp. 33-51.

Resnick, M., Kafai, Y., \& Maeda, J. (2003). A Networked, Media-Rich Programming Environment to Enhance Technological Fluency at After-School Centers in Economically-Disadvantage Communities. United States.

Riehle, D., \& Bruckman, A. (2009). Proceedings of the 5th International Symposium on Wikis and Open Collaboration 2009. Orlando, Florida: ACM.

Robertson, J., \& Howells, C. (2008). Computer game design: Opportunities for successful learning, Computers \& Education, Vol. 50, No. 2, pp. 559-578.

Rusk, N. (2009a). Scratch Programming Concepts, Retrieved September 5, 2011, from: http://info.scratch.mit.edu/sites/infoscratch.media.mit.edu/files/file/ScratchProgrammingConcept s-v14.pdf

Rusk, N. (2009b). Scratch Cards, Retrieved September 5, 2011, from: http://scratched.media.mit.edu/resources/scratch-cards

Schifter, K. (2012). Minecraft in an English Class, Poster presented at 6th European Conference on Games Based Learning. Cork, Ireland, 4-5 October 2012

Scottish Executive (2006). A Curriculum for Excellence: Building the Curriculum 3-18(1).

Scottish Executive (2008). A Curriculum for Excellence: Building the Curriculum 3-18 (3).

Silius, K., Miilumäki, T, Huhtamäki, J., Tebest, T., Meriläinen, J., \& Pohjolainen, S. (2010). Students' Motivations for Social Media Enhanced Studying and Learning. Knowledge Management \& ELearning: An International Journal, Vol.2, No.1. 51. 
Games For and By Teachers and Learners to appear in Connolly, T.M., Boyle, E., Hainey, T., Baxter, G. \& Moreno-Ger, P. (Eds) Psychology, Pedagogy and Assessment in Serious Games.

Sivilotti, P. A. G., \& Laugel, S. A. (2008). Scratching the Surface of Advanced Topics in Software Engineering: A Workshop Module for Middle School Students. Learning, 291-295.

Sloep, P. B., Van der Klink, M., Brouns, F., Van Bruggen, J., \& Didderen, W. (Eds.) (2011).

Leernetwerken; Kennisdeling, kennisontwikkeling en de leerprocessen. Houten, Nederland: Bohn, Stafleu, Van Loghum.

Ten Brummelhuis, A., \& Van Amerongen, M. (2010). Vier in Balans Monitor 2010: Ict in het onderwijs: de stand van zaken (Monitor 2010: Ict in education: the state of affairs). Kennisnet. Retrieved February 2, 2011, from http://onderzoek.kennisnet.nl/vierinbalansmonitor.

Ternier, S., Klemke, R., Kalz, M., Van Ulzen, P., \& Specht, M. (2012). ARLearn: augmented reality meets augmented virtuality [Special issue]. Journal of Universal Computer Science - Technology for learning across physical and virtual spaces.

Torrente, J., Del Blanco, Á., Marchiori, E.J., Moreno-Ger, P., \& Fernández-Manjón, B. (2010). <eAdventure>: Introducing Educational Games in the Learning Process. Proceedings of the IEEE EDUCON 2010 Conference (Special issue e-Madrid), 14-16 April 2010, Madrid, Spain. 2010.

Van Rosmalen, P., \& Westera, W. (2012). Introducing Serious Games with Wikis: Empowering the Teacher with simple Technologies. Interactive Learning Environments. DOI:10.1080/10494820.2012.707128

Vier in Balans Monitor 2012 (2012). Retrieved December 5, 2012, from: http://www.kennisnet.n1/fileadmin/contentelementen/kennisnet/Over.kennisnet/vier-in-balans2012.pdf

Westera, W., Nadolski, R.J., Hummel, H.G.K., \& Wopereis, I. (2008). Serious games for higher education: a framework for reducing design complexity. Journal of Computer Assisted Learning, 24(5), 420-432.

Williamson, B. (2009). Computer games, schools, and young people. A report for educators on using games for learning. Futurelab: Bristol. Retrieved from:

http://archive.futurelab.org.uk/resources/documents/project_reports/becta/Games_and_L earning_educators_report.pdf

Wilson, A. Connolly, T.M. Hainey, T., \& Moffat, D. (2011). Evaluation of Introducing Programming to Younger School Children Using a Computer Game Construction Application, In Proceedings of 5th European Conference on Games-based Learning, 20-21 October 2011, Athens, Greece.

Wilson, A. Hainey, T., \& Connolly, T. (2012). Evaluation of Computer Games Developed by Primary School Children to Gauge Understanding of Programming Concepts. In Proceedings of the 6th European Conference on Games Based Learning. Cork, Ireland, 4-5 October 2012 